Sosialisasi dan Latihan Teknik....(Bambang Hermansah)

\title{
SOSIALISASI DAN LATIHAN TEKNIK DASAR OLAHRAGA BOLA TANGAN DI LEMBAGA PEMBINAAN KHUSUS ANAK (LPKA) KELAS I PAKJO PALEMBANG
}

\author{
Oleh: Bambang Hermansah \\ (Dosen Universitas PGRI Palembang) \\ Email : bambang.hermansah@gmail.com
}

\begin{abstract}
Abstrak
Tujuan penelitian ini untuk mensosialisasikan olahraga bola tangan dan melatih keterampilan teknik dasar warga binaan, serta untuk meningkatkan minat dan partisipasi dalam kegiatan ekstrakurikuler di LPKA. Metode penelitian yang digunakan adalah eksperimen dengan pendekatan deskriptif kuantitatif, desain penelitian one grup pretest-posttest. Populasi penelitian ini adalah 28 orang warga binaan. Instrumen penelitian menggunakan judgement expert, yang bertujuan untuk mengetahui hasil sosialisasi dan latihan teknik dasar bola tangan. Berdasarkan data yang telah diperoleh, kesimpulan dari penelitian sosialisasi dan latihan teknik dasar bola tangan efektif diberikan pada Warga Binaan Lembaga Pembinaan Khusus Anak (LPKA) Kelas I Pakjo Palembang, dengan dibuktikan dari nilai $t_{\text {hitung }}>t_{\text {tabel }}$ atau 5,39 $>3,19$. Dengan taraf signifikan 0,05 dan besar pengaruh 11,1\%.
\end{abstract}

Kata Kunci : Sosialisasi, Teknik Dasar, Warga Binaan, Bola Tangan.

\section{SOCIALIZATION OF HANDLING SPORTS BASIC TECHNIQUES AND EXERCISES IN LEMBAGA PEMBINAAN KHUSUS ANAK (LPKA) CLASS I PAKJO PALEMBANG}

\begin{abstract}
The purpose of this study was to socialize handball and train basic technical skills of inmates, as well as to increase interest and participation in extracurricular activities in LPKA. The research method used was an experiment with a quantitative descriptive approach, one group pretest-posttest research design. The population of this study were 28 inmates. The research instrument uses expert judgment, which aims to find out the results of socialization and basic handball training techniques. Based on the data that has been obtained, the conclusion of the effective handball basic exercise socialization and training research was given to the residents of the Pakjo Palembang Special Class Child Development Institution (LPKA), as evidenced from the $t_{\text {count }}>t_{\text {table }}$ or 5.39> 3.19. With a significant level of 0.05 and a large influence of $11.1 \%$.
\end{abstract}

Keywords : Socialization, Basic Techniques, Patronage Citizens, Handball. 
Wahana Didaktika Vol. 16 No.2 Mei 2018 : 185-192

\section{A. PENDAHULUAN}

Olahraga merupakan satu-satunya kegiatan yang mampu menyatukan semua elemen masyarakat tanpa memandang suku, ras maupun agama. Sehingga tak seorang pun di dunia ini yang tidak menyukai kegiatan olahraga. Mulai dari rakyat jelata hingga para pejabat serta pemimpin Negara. Hal ini terjadi karena satu tujuan yaitu menciptakan tubuh yang kuat dan jiwa yang sehat (Hermansah, 2018).

Olahraga bola tangan bersifat indoor. Olahraga bola tangan merupakan suatu permainan yang dimainkan oleh dua regu yang masing-masing terdiri dari tujuh orang. Tiap-tiap regu berusaha memasukkan bola ke dalam gawang regu lawan dan mencegah regu lawan memasukkan bola. Bola boleh dipasing dengan tangan atau dengan mendribelnya beberapa kali ke lantai tanpa menyentuh kedua tangan bersamaan (Hermansah, 2016).

Olahraga bola tangan indoor di Indonesia pada masa sekarang ini belum memasyarakat bila dibandingkan dengan cabang olahraga lainnya seperti sepakbola, futsal, basket, bolavoli. Hal ini dikarenakan belum dilakukan sosialisasi kepada masyarakat, khususnya warga binaan. Padahal olahraga bola tangan memiliki potensi besar di tingkat sekolah, mengingat olahraga bola tangan adalah olahraga dinamis yang sebenarnya menarik untuk diperkenalkan kepada masyarakat/sekolah. Untuk itu, sosialisasi perlu dilakukan dan menjadi agenda tetap pengurus Asosiasi Bola Tangan Indonesia (ABTI) kota Palembang.

Seperti yang telah diamanatkan dalam Undang-Undang nomor 3 tahun 2005 tentang Sistem Keolahragaan Nasional pasal 21 "pembinaan dan pengembangan keolahragaan dilaksanakan melalui tahap pengenalan olahraga, pemantauan, pemanduan, serta pengembangan bakat dan peningkatan prestasi”, serta pasal 23 “masyarakat dapat melakukan pembinaan dan pengembangan olahraga melalui berbagai kegiatan keolahragaan secara aktif, baik yang dilaksanakan atas dorongan Pemerintah dan atau pemerintah daerah, maupun atas kesadaran atau prakarsa sendiri”.

Furqon (2005) mengatakan bahwa "sosialisasi olahraga bertujuan untuk mendorong dan menggerakkan masyarakat agar lebih memahami dan menghayati langsung hakikat dan manfaat olahraga sebagai kebutuhan hidup, khususnya jenis olahraga yang bersifat mudah, murah, menarik, bermanfaat. Sosialisasi dapat pula berfungsi sebagai wahana 
Sosialisasi dan Latihan Teknik....(Bambang Hermansah)

dalam penelusuran bibit-bibit untuk membentuk atlet berprestasi. Sosialisasi olahraga merupakan dasar dari teori piramida dan sekaligus merupakan landasan dalam proses pembibitan dan pemanduan bakat atlet”. Kegiatan sosialisasi kegiatan olahraga bola tangan ini menanamkan teknik dasar gerak dalam rangka pembinaan softskill dan mendorong kondisi fisik dan mental yang sehat dan kuat bagi warga binaan. Sehingga warga binaan menjadikan olahraga sebagai salah satu olahraga yang dilakukan di LPKA Kelas 1 Pakjo Palembang.

Kegiatan tersebut melalui beberapa tahap, yaitu pertama kegiatan sosialisasi olahraga kepada masyarakat secara khusus warga binaan untuk menanamkan dasardasar keterampilan gerak dalam usaha mencari bibit-bibit atlet yang berbakat dengan kondisi fisik dan mental yang sehat dan kuat untuk dikembangkan dalam mencapai prestasi yang tinggi. Kegiatan kedua memperkenalkan olahraga bola tangan beserta teknik dasar permainannya. Sejalan dengan pendapat Hermansah (2016), “dalam proses belajar mengajar bola tangan, pemain dibekali dengan teknik dasar yang baik. Pemain yang memiliki teknik dasar yang baik pemain tersebut cenderung dapat bermain bola tangan dengan baik pula. Teknik dasar tersebut dapat dibagi sebagai berikut : teknik menangkap bola, teknik menembak (shooting), teknik mendribble bola, dan teknik mengoper bola (passing).

Teknik menangkap bola merupakan teknik dasar yang sangat penting dan pertamatama yang seharusnya perlu dikuasai oleh setiap permainan, apakah itu pemain depan, permainan tengah, pemain belakang lebih-lebih penjaga gawang yang memang memerlukan kecakapan dalam menangkap bola. Bagaimana posisi badan dan tangan pada saat menangkap bola, tekniknya dengan menjulurkan kedua tangan ke depan menyambut datangnya bola setelah bola dalam penguasaan, secepat mungkin ditarik di depan dada.

Teknik menembak (shooting) adalah bentuk gerak lemparan yang ditujukan untuk memasukkan bola ke gawang. Agar berhasil, lemparan yang dilakukan harus bertenaga dan memiliki daya ledak (eksplosif power) dengan artian mengarahkan seluruh kecepatan dan kekuatan dalam waktu yang sangat singkat sehingga menghasilkan gerak laju bola yang cepat. Menembakkan bola harus dilakukan dengan upaya yang sungguhsungguh sehingga menghasilkan perbedaan sikap tubuh yang disesuaikan. Yang paling 
menarik adalah pelaksanaan tembakan fliying shot yang memerlukan irama tiga langkah.

Teknik mendribble merupakan teknik dasar yang cukup sulit karena memerlukan kordinasi mata-tangan yang tinggi, dan harus jeli dan pandai saat memantulkan bola supaya lentingan bola tepat dan tetap dalam penguasaan si penggiring. Menggiring atau dribbling bola juga memerlukan kelenturan tubuh pada saat membungkuk guna mengontrol bola yang ada dalam penguasaan si penggiring di samping itu kelenturan pergelangan tangan tidak kalah pentingnya dalam hal mengantisipasi bola yang sementara digiring. Konsentrasi pada saat menggiring bola ke arah daerah pemain lawan sangat dibutuhkan, serta diiringi dengan kordinasi mata-tangan atau kerja sama antara tangan pada saat melakukan dribbling supaya bola tetap dalam penguasaan dan tidak mudah terlepas dari jangkauan si penggiring.

Salah satu kendala yang bisa dialami pemain yang bermain di lapangan terbuka (outdoor) dalam menggiring bola adalah permukaan lapangan yang tidak rata sehingga menambah tingkat kesulitan pelaksanaan dribbling tersebut. Perlu diingat bahwa arah pantulan bola akan tergantung pada arah datang dari bola itu ke tanah. Dengan demikian, pelaksanaan pantulang antara dribbling di tempat dan dribbling sambil bergerak memerlukan penyesuaian gaya dan sikap tubuh pada saat mendribbling. Dribbing itu pada hakekatnya terdiri dari dua bagian yaitu dribbling lurus dan dribbling silang. Khusus dribbling silang memerlukan kelincahan, skill dan kordinasi mata-tangan yang tinggi.

Teknik mengoper bola (passing) merupakan teknik yang sangat penting dalam operan bola dari tangan ke tangan sangat penting dalam usaha membangun sebuah serangan ke daerah pertahanan lawan, guna menghasilkan sebuah gol. Passing dalam hakekatnya terbagi dalam dua bagian yaitu passing dengan dua tangan dan passing dengan satu tangan. Passing dangan dua tangan diperlukan terutama untuk operanoperan jarak dekat, namun perlu dilakukan dengan secara cepat. Untuk itu, pemakaian teknik mana yang harus dipilih tergantung dari posisi pemain seregu dan pemain lawan yang menghadang. Passing satu tangan, dilihat dari jenisnya, dapat dibedakan berdasarkan dua tujuan, yaitu pertama, untuk mengoper pada teman seregu yang berjarak jauh dan yang kedua mongoper untuk mengecoh lawan. 
Sosialisasi dan Latihan Teknik....(Bambang Hermansah)

Banyak faktor kurangnya minat masyarakat terhadap olahraga bola tangan, diantaranya belum mengetahui cara bermain maupun peraturannya, kurangnya pengenalan olahraga bola tangan secara langsung pada masyarakat luas dan secara terprogram, tidak ada yang memperkenalkan atau melakukan demonstrasi-demonstrasi di masyarakat maupun di lingkungan Sekolah. Maka tujuan penelitian ini untuk meningkatkan minat dan partisipasi dalam mengikuti kegiatan olahraga bola tangan, serta bisa menjadi bahan acuan untuk memperkenalkan dan melatih keterampilan teknik dasar bola tangan di lingkungan Sekolah, khususnya LPKA.

\section{B. METODOLOGI PENELITIAN}

Metode penelitian adalah cara yang digunakan oleh peneliti dalam mengumpulkan data penelitiannya (Arikunto, 2013:203). Berdasarkan pendapat tersebut, maka dalam penelitian ini metode yang akan digunakan adalah metode eksperimen. Metode eksperimen dapat diartikan sebagai metode yang digunakan untuk mencari pengaruh perlakuan terhadap yang lain dalam kondisi yang terkendali. Metode penelitian yang digunakan adalah eksperimen dengan pendekatan deskriptif kuantitatif, desain penelitian one grup pretest-posttest.

"Desain ini melibatkan satu kelompok yang diberi pre-test (01), diberi satu treatment (x) dan diberi post-test (02). Keberhasilan treatment ditentukan dengan membandingkan nilai pre-test dan post-test" (Darmadi, 2011:200). Prosedur penelitian adalah "sebuah titik tolak pemikiran yang akan membantu pelaksanaan kegiatan lebih efektif dan bagaimana cara merancang yang berguna terhadap penelitian. kemudian untuk dianalisis dan mencari perannya sehingga dapat digunakan sebagai kesimpulan yang diharapkan". Peneliti ini dilakukan untuk mengetahui seberapa besar pengaruh modifikasi permainan bola tangan (x) yaitu variabel bebas, sedangkan hasil belajar passing Bola Tangan, yaitu variabel terikat (y).

Menurut Sugiyono, (2010:117), populasi adalah yang terdiri generalisasi atas objek/subjek yang mempunyai kualitas dan karakteristik tertentu yang diciptakan oleh peneliti untuk dipelajari dan ditarik kesimpulannya. Populasi penelitian ini adalah 28 orang warga binaan LPKA Kelas I Pakjo Palembang. Instrumen penelitian menggunakan judgement expert, yang bertujuan untuk mengetahui sosialisasi dan hasil 
Wahana Didaktika Vol. 16 No.2 Mei 2018 : 185-192

belajar teknik dasar bola tangan.

\section{HASIL DAN PEMBAHASAN}

Hasil analisis kebutuhan diketahui olahraga bola tangan masih belum memasyarakat dan kalah populer dengan olahraga seperti futsal, sepakbola, bolavoli, hal tersebutlah sebagian besar masyrakat belum memperkenalkan olahraga bola tangan, terutama lingkungan lembaga pembinaan khusus anak, hal ini dikarenakan petugas masih belum terlalu yakin dengan antusias warga binaan ketika diperkenalkan olahraga khususnya olahraga bola tangan tersebut. Selain itu, petugas LPKA mengemukakan bahwa belum ada sosialisasi tentang peraturan di dalam permainan bola tangan di LPKA karena sebelumnya memang belum pernah ada yang mensosialisasikan olahraga bola tangan maupun peraturan permainannya.

Peneliti memberikan pretest terlebih dahulu yang bertujuan untuk mendapatkan data awal. Pelaksanaan pretest teknik dasar bola tangan dengan menggunakan judgement expert. Setiap warga binaan diminta untuk mempraktekan teknik dasar satu persatu. Hasil pretest tersebut, kemudian dihitung oleh peneliti. Kemudian peneliti dapat memberikan perlakuan berupa teknik dasar olahraga bola tangan yang benar dan tepat, untuk meningkatkan teknik dasar bola tangan. Setelah itu dilakukan posttest untuk melihat sejauh mana sosialisasi dan latihan teknik dasar permainan bola tangan pada warga binaan LPKA Kelas I Pakjo Palembang.

Dari tabel di atas, dapat diketahui bahwa perbandingan nilai pretest dan posttest pada warga binaan dengan jumlah 28 siswa, yaitu dilihat dari nilai pre test memiliki rata-rata sebesar 53, standart deviasi 11,4, dengan varian 178,2 nilai minimun 40 dan nilai maksimum 65. Sedangkan untuk nilai posttest didapatkan nilai rata-rata sebesar 72, standart deviasi 9,6, dengan varian 141,5 nilai minimun 60 dan nilai maksimum 95.

Nilai beda antara pretest dan posttest untuk rata-rata adalah sebesar 19, standar deviasi sebesar $-1,8$ dengan varian sebesar $-36,7$ dan beda nilai minimum pretest dan posttest sebesar 20 sedangkan beda nilai maksimum pre test dan post test sebesar 20. Sehingga dari hasil tersebut besar pengaruh antara pre test dan post test sebesar $11,1 \%$ yang berarti bahwa sosialisasi dan latihan teknik dasar bola tangan pada warga binaan Lembaga Pembinaan Khusus Anak (LPKA) Kelas I Pakjo Palembang. Perhitungan 
Sosialisasi dan Latihan Teknik....(Bambang Hermansah)

hipotesis dengan menggunakan Uji-t yakni uji paired sampel T Test dan diperoleh pada taraf signifikan 0,05 menunjukan bahwa thitung 5,39 sedangkan tabel sebesar 3,19 dengan taraf signifikan $\alpha=0,05$. Berdasarkan pengambilan keputusan di atas maka thitung $>$ tabel $(5,39>3,19)$.

Pada uji normalitas untuk mengetahui sebaran data yang diperoleh dari hasil pretest dan posttest berdistribusi normal atau tidak. Dengan menggunakan bantuan program SPSS 20.00 dalam menghitung uji normalitas dihasilkan nilai sig.(2-tailed) pada Kolmogorov-smirnov yang dapat menunjukkan normal atau tidak nya sebaran data. Sebuah syarat data berdistribusi normal apabila signifikansi yang diperoleh lebih besar dari tingkat alpha 5\% (signifikansi > 0,05).

\section{SIMPULAN}

Berdasarkan hasil penelitian dan analisis data, maka dapat disimpulkan bahwa penelitian sosialisasi dan latihan teknik dasar bola tangan efektif diberikan pada 28 orang warga binaan Lembaga Pembinaan Khusus Anak (LPKA) Kelas I Pakjo Palembang. Hal ini terlihat dari Nilai beda antara pretest dan posttest untuk rata-rata adalah sebesar 19, standar deviasi sebesar -1,8 dengan varian sebesar -36,7 dan beda nilai minimum pretest dan posttest sebesar 20 sedangkan beda nilai maksimum pre test dan post test sebesar 20. Sehingga dari hasil tersebut besar pengaruh antara pre test dan post test sebesar 11,1\%. Perhitungan hipotesis dengan menggunakan Uji-t yakni uji paired sampel $\mathrm{T}$ Test dan diperoleh pada taraf signifikan 0,05 menunjukan bahwa thitung 5,39 sedangkan ttabel sebesar 3,19 dengan taraf signifikan $\alpha=0,05$. Berdasarkan pengambilan keputusan di atas maka thitung $>\mathbf{t}_{\text {tabel }}(5,39>3,19)$. 
Wahana Didaktika Vol. 16 No.2 Mei 2018 : 185-192

\section{DAFTAR PUSTAKA}

Arikunto, S. 2013. Prosedur Penelitian: Suatu Pendekatan Praktik. Jakarta: Rineka Cipta.

Darmadi, Hamid. 2011. Metode Penelitian Pendidikan. Bandung: Alfabeta.

Furqon. Hidayatuloh. 2005. Pembangunan Olahraga bagian intergral dari pembangunan bangsa. Disampaikan dalam pengukuhan guru besar ilmu keolahragaan. (http://si.uns.ac.id/profil/uploadpublikasi/pengukuhan/ORASI/ FURQON.doc).Diakses: tanggal 7 Mei 2018.

Hermansah, Bambang. 2016. Pengaruh Latihan Bola Digantung terhadap Hasil Shooting pada Siswa Ekstrakurikuler Bola Tangan Kelas VIII SMP N 5 Indralaya Utara. Prosiding Dosen Universitas PGRI Palembang Edisi 19. Jurnal Dosen Universitas PGRI Palembang.

Hermansah, Bambang. 2018. Modifikasi Permainan Bola Tangan terhadap Hasil Belajar Passing dalam Pembelajaran Bola Tangan Mahasiswa. Wahana Didaktika: Jurnal Ilmu Kependidikan (Online). Volume 16 No.1 Januari 2018 : 35-41. FKIP Universitas PGRI Palembang.

Kemenegpora Republik Indonesia. 2005. Undang-Undang Republik Indonesia No.3 Tahun 2005 Tentang Sistem Keolahragaan Nasional. Jakarta: Kemenegpora.

Sugiyono. 2010. Statistik untuk penelitian. Bandung: Alfabeta. 